\title{
Polarographic Studies of Proteins and their Degradation Products. V. Products from Tryptic Digests of Serum Albumin and Development of a Sensitive Polarographic Trypsin Assay.*
}

\author{
Otto H. Müller and Itsuro Yamanoughi** \\ (Department of Physiology, State University of New York, \\ Upstate Medical Center, Syracuse 10, New York) \\ To Professor Isamu Tachi on his 63rd birthday.
}

(Received Nov. 2, 1962)

Plasma protein fractions show characteristic differences in their polarographic behavior after being subjected to alkaline digestion ${ }^{1,2}$. Serum albumin (fraction V) in particular is unique in that it produces a catalytic double-wave in divalent cobalt buffer which increases markedly during the first 10-20 minutes of digestion and then decreases gradually during the following hour. During this same period of digestion no sulfosalicylic acid-soluble split products are formed which produce catalytic polarographic waves in trivalent cobalt buffer. When the same albumin is subjected to tryptic digestion instead of alkaline denaturation, the results are quite different. Not only does the doublewave in divalent cobalt buffer increase without a decay reaction ${ }^{2}$ (at least during 5 hours) as the digestion progresses, but also split products are formed that are sulfosalicylic acid-soluble and give a catalytic wave in trivalent cobalt buffer. This catalytic wave is peculiar in that it shows only the first peak of the catalytic double wave $e^{3,4}$. This finding led to a more detailed study of the proteolytic action of trypsin which involved an investigation of the stability of trypsin preparations $s^{5}$ and a comparison of polarographic data with known methods for the assay of tryptic activity ${ }^{6}$, as far as possible. It has also led to the development of a sensitive and rapid polarographic method for assaying the activity of trypsin which is presented here.

Trypsin and its proteolytic action have been studied polarographically on numerous occasions. It was found that trypsin itself, like other proteins, produces a catalytic double wave in divalent cobalt buffer ${ }^{7}$ and that the relationship between trypsin concentration and wave height resembles a Langmuir adsorption isotherm ${ }^{8)}$. The wave height of trypsin is much smaller than that of plasma at corresponding concentrations and the second wave

*) Supported in part by Grant No. G 2358 from the Division of Research Grants and Fellowships of the National Institutes of Health, U. S. Public Health Service.

**) Present address : Department of Pediatrics, National Hospital of Okayama, Okayama-shi, Japan. 
is always higher than the first wave, even in the most dilute solutions ${ }^{7}$.* Tryptic digestion of fibrinogen") or insulin ${ }^{10)}$ increases their polarographic wave heights as the digestion proceeds. However, in the case of ovalbumin, preliminary alkaline denaturation is necessary before the effects of tryptic digestion can be ascertained polarographically ${ }^{11}$. The first wave then decreases during the course of the tryptic digestion while the second wave increases for 20-40 minutes (depending on $\mathrm{pH}$ ) before it, too, decreases. Sulfosalicylic acid-soluble split products resulting from tryptic digestion have also been studied. They are usually analyzed in trivalent cobalt buffer to eliminate the effect of any cysteine that may be present. Thus alkaline-denatured ovalbumin ${ }^{11)}$ or fresh $\operatorname{dog} \operatorname{ser}^{12)}$ were found to give catalytic double-waves which increased with the time of the tryptic digestion, but no measurable differences existed between sera from normal and infected $\operatorname{dogs}^{12}$. The polarographic analysis of split products resulting from the digestion of serum albumin has been proposed as a method of trypsin assay by Stokrova $^{13)}$ but so far has not been tested on samples of known activity.

Stokrova states ${ }^{13}$ that "at the given concentration, the double wave merges into a single maximum," but from her published polarograms it is obvious that the contribution of the second wave is extremely small. Yet there seems to be a definite difference between this and our own observation of a pure first wave in similar filtrates ${ }^{3,4}$ which warranted further investigation, especially since typical polarographic double waves had been observed in earlier work ${ }^{11,12)}$. From the data presented here it will become clear that the state of the protein, whether native or denatured, has an important influence on the polarographic behavior of the products formed during the tryptic digestion. That these products are indeed different is also concluded on the basis of dilution curves. These are suggested as a new method for the characterization of polarographically active substances that produce catalytic waves.

\section{Experimental}

\section{Chemicals :}

A. Trypsin: Seven different trypsin preparations were used. They were usually dissolved in pH 7.1 phosphate buffer and used as quickly as possible to avoid self-digestion. After we had established that certain trypsin samples were quite stable in distilled water ${ }^{5}$, we repeated some of the experiments with unbuffered trypsin preparations and ascertained that our principal observations remained unaltered.

The activity of the trypsin preparations was determined by several methods. Besides Anson's modification ${ }^{14}$ of the hemoglobin method ${ }^{15}$, we used Kunitz's method $^{16)}$ with "Hammarsten Quality" casein as a substrate, and Schwert and Takenaka's method" in which N-benzoyl-L-arginine ethyl ester serves as substrate. All three methods yielded results in which the relative values of the activity of the different preparation were essentially the same ${ }^{b}$.

*) In an exploratory study of four different trypsin preparations we found this to be true except for very dilute solutions (less than $1 \mathrm{mg} . \%$ ) of the purest samples, but the ratio of the two wave heights varied from sample to sample. Compared on the basis of the protein nitrogen content of the solutions, the height of the first wave reflected to some extent the proteolytic activity of the sample, while the height of the second wave seemed to be related to its purity. 
The trypsin preparations used were:

$\left(\mathrm{A}_{\mathrm{L}}\right)$ : Sterile, lyophilized, crystalline, from Armour Laboratories, Kankakee, Ill. Tryptar, Lots 43206, P55311, R56308. Activity $5.8 \times 10^{-3}$ [TU] $]_{\text {nog }}^{\text {Hb }}{ }^{\text {5) }}$ This will serve as reference with $100 \%$ activity for the comparison of other preparations in this paper.

$\left(\mathrm{W}_{\mathrm{L}}\right)$ : Sterile, lyophilized, crystalline, from Worthington Biochemical Corp., Freehold, N.J., Lot TRL 570. Activity about $66 \%$.

$\left(\mathrm{W}_{2 \mathrm{x}}\right)$ : Twice-crystallized (salt-free), from Worthington Biochemical Corp., Freehold, N.J., Lot TRSF 573-75. Activity about $120 \%$.

$\left(\mathrm{G}_{\mathrm{x}}\right.$ and $\left.\mathrm{G}_{2 \mathrm{x}}\right)$ : Once- and twice-crystallized, salt-free samples from General Biochemicals, Inc., Chagrin Falls, Ohio, Lots 29416 and 31169. Activity about 99 and $97 \%$, respectively.

$\left(\mathrm{G}_{\mathrm{U}}\right)$ : Non-crystalline, trypsin 4-USP from General Biochemicals, Inc., Chagrin Falls, Ohio, Lot 30775. Activity about $7 \%$.

(P): A non-crystalline, 10-year-old specimen of trypsin 1:110 from Paragon Testing Laboratories, Orange, N.J. Activity about $9 \%$.

B. Protein Substrates: Most of the studies were carried out with crystalline bovine albumin (CBA) from Armour Laboratories, Kankakee, Ill., dissolved in pH 7.1 phosphate buffer. Other proteins, used for comparison, were samples of human plasma proteins, either received through the kindness of Dr. Mulford from the Division of Biological Laboratories of the Massachusetts Department of Public Health, or prepared in our own laboratory by Cohn's alcohol fractionation procedures, method $10^{18}$.

C. All other chemicals: The best grade obtainable was used without further purification.

Determination of Protein Concentration: The enzyme and substrate concentrations were measured either by a biuret method ${ }^{19}$ in which the optical density was read at $540 \mathrm{~m} \mu$, or by a direct method in which the extinction was measured at $280 \mathrm{~m} \mu$. For the latter we found a conversion factor of 0.65 to give more concordant results with the biuret method ${ }^{5)}$ than when we used the factor 0.64 as suggested by Worthington ${ }^{20}$ or the factor of 0.585 as suggested by Kunitz ${ }^{16}$. These analyses were occasionally checked by Kjeldahl nitrogen determinations. Protein concentrations stated in Figures and Tables are those of the tryptic digests, not those of the starting solutions.

Standard DiCo Buffer: The standard divalent cobalt (DiCo) buffer consisted of : 3.2 $\times 10^{-3} M$ cobaltous chloride, $0.1 \mathrm{~N}$ ammonium chloride, and $0.1 \mathrm{~N}$ ammonium hydroxide. It has to be freshly prepared ${ }^{4}$.

Standard TriCo Buffer: The standard trivalent cobalt (TriCo) buffer consisted of : $1 \times$ $10^{-3} M$ hexamminecobaltic chloride, $0.1 \mathrm{~N}$ ammonium chloride, and $0.8 \mathrm{M}$ ammonium hydroxide. It is stable for some time ${ }^{4}$.

Polarographic Equipment: The data were obtained with a Sargent Model XII Polarograph which contained a galvanometer with a maximum sensitivity of $5.2 \times 10^{-9} \mathrm{~A} . / \mathrm{mm}$. Although several capillaries were used in this study the present report is concerned mainly with data obtained with a single capillary of the following characteristics; $\kappa=$ 
14.1, $\rho=23.9 \mu$. At an applied voltage of $-1.6 \mathrm{v}$. and an effective pressure of $48.4 \mathrm{~cm}$ $\mathrm{Hg}$, the drop time was 1.32 seconds, the drop weight $4.62 \mathrm{mg}$. and the surface of the "ripe" drop $2.36 \mathrm{~mm}^{2}$. when the electrode was dropping in cobalt buffer. The data of Figure 7 were obtained with another capillary $(\kappa=41.2 ; \rho=16.8 \mu ; t=1.70$ seconds, and $A=1.87$ $\mathrm{mm}^{2}$. in cobalt buffer at $-1.6 \mathrm{v}$.). The anode was a saturated calomal half-cell connected to the test solution by a saturated potassium chloride-agar bridge.

All polarographic analyses were carried out open to the air, at room temperature. The results reported here are essentially those obtained at $25^{\circ} \mathrm{C}$., each curve starting at - $1.0 \mathrm{v}$ (vs. SCE).

The $\mathrm{pH}$ of the buffers was measured with a Beckman $\mathrm{pH}$ meter, Model G.

\section{Results}

Effect of Trypsin on Large Protein Molecules: Besides splitting off certain products, trypsin seems to alter the structure of the substrate protein, as evidenced by a change in the polarographic double wave, (largely a change in the second wave) in divalent cobalt buffer. To see this effect one must employ rather high concentrations of enzyme protein.

Procedure I : Mix $0.5 \mathrm{ml}$ of a $5 \mathrm{~g} / 100 \mathrm{ml}$ solution of crystalline bovine albumin in $M / 15$ phosphate buffer of $\mathrm{pH} 7.1$ and $0.5 \mathrm{ml}$ of freshly prepared trypsin solution $(0.01$ to $0.5 \mathrm{~g} / 100 \mathrm{ml})$ in the same buffer. Digest the mixture in a water bath at $37^{\circ} \mathrm{C}$. Remove from it $0.05 \mathrm{ml}$ samples at known intervals of time (up to 5 hours) and add them to $10.0 \mathrm{ml}$ of DiGo buffer. Polarograph the resulting mixture immediately, at room temperature, starting at $-1.0 \mathrm{v}$ (vs. SCE).

For buffer blank (BB) add $0.05 \mathrm{ml}$ of phosphate buffer (pH 7.1) to $10.0 \mathrm{ml}$ DiCo buffer.

For enzyme blank (EB) mix $0.2 \mathrm{ml}$ of the trypsin solution with $0.2 \mathrm{ml}$ phosphate buffer and add $0.05 \mathrm{ml}$ of the mixture to $10.0 \mathrm{ml}$ DiCo buffer. If the $\mathrm{EB}$ is large, prepare a similar mixture and digest it for the same length of time as the unknown samples before adding aliquots to the DiCo buffer.

For protein blank (PB) mix $0.2 \mathrm{ml}$ of the albumin solution with $0.2 \mathrm{ml}$ phosphate buffer and add $0.05 \mathrm{ml}$ of the mixture to $10.0 \mathrm{ml}$ of DiCo buffer.

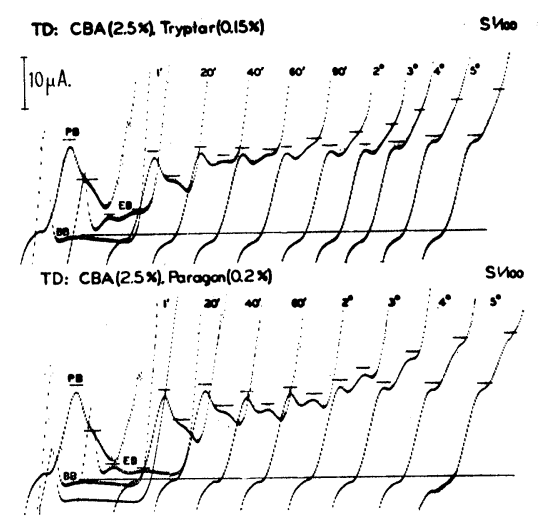

Fig. 1. Tryptic digests of $2.5 \mathrm{~g} / 100 \mathrm{ml} \mathrm{CBA}$ in $\mathrm{pH} 7.1$ phosphate buffer as a function of time (Procedure I). Upper Polarogram : Trypsin $\left(\mathrm{A}_{\mathrm{L}}\right), 0.15 \mathrm{~g} / 100 \mathrm{ml}$; Lower Polarogram : Trypsin (P), $0.2 \mathrm{~g} / 100 \mathrm{ml}$. BB : Buffer blank ; PB : Protein blank ; EB : Enzyme blank.
The results of such analyses in a buffer of $\mathrm{pH} 7.1$ are shown in Figure 1 for two trypsin preparations of about equal concentration. Note that their effects are essentially the same although the known activity of trypsin $(\mathrm{P})$ is less than $10 \%$ of the tryptic activity of tryp$\sin \left(\mathrm{A}_{\mathrm{L}}\right)$. One may conclude, therefore, that the reaction studied is perhaps influenced more by other enzymes that may be present as impurities. This finding would be in accord with that of Northrop ${ }^{21)}$ who compared crude and crystalline trypsin peparations. 
As may be seen from Figure 2, a much more dilute solution of trypsin $\left(A_{L}\right)$ hardly shows an effect in this procedure I. Yet this same concentration of trypsin liberates split products at a very rapid rate, as will be shown next.

Split products from serum albumin produced by tryptic digestion: Liberation of these products is followed polarographically by analysis of sulfosalicylic acid filtrates of the tryptic digests in trivalent cobalt buffer.

Procedure II : Mix $0.5 \mathrm{ml}$ of a $5 \mathrm{~g} / 100$ $\mathrm{ml}$ solution of crystalline bovine albumin in $M / 15$ phosphate buffer of $\mathrm{pH} 7.1$ and $0.5 \mathrm{ml}$ of freshly prepared trypsin solution ( 0.001 to $0.5 \mathrm{~g} / 100 \mathrm{ml}$, depending on activity) in the same buffer. Digest the mixture in a water bath at $37^{\circ} \mathrm{C}$. Remove $0.5 \mathrm{ml}$ samples at known intervals of time, add them to $0.5 \mathrm{ml}$ of a solution of 20 $\mathrm{g} / 100 \mathrm{ml}$ sulfosalicyclic acid and shake the mixture. After 10 minutes'standing, filter the solution through Whatman No. 5 filter paper. When convenient, add 0.5 $\mathrm{ml}$ of the clear filtrate to $5.0 \mathrm{ml}$ of standard Trico buffer. Analyze the resulting mixture polarographically, open to air, at room temperature.

The comparison blanks are prepared as in procedure $I$ and then subjected to sulfosalicylic acid treatment and filtration as above.

To illustrate this type of analysis, the filtrates from a dilute trypsin $\left(\mathrm{A}_{\mathrm{L}}\right)$ and a 40 times as concentrated trypsin $(\mathrm{P})$ digest have been selected and are presented in

Figure 3. The activity of the crude preparation is thus about four times that of the crystalline preparation. Notice that in both instances the wave height increases rapidly for the first hour and thereafter continues to increase more slowly. When the trypsin content is reduced, as in Figure 4, the rate of rise of the polarographic wave height is considerably slower, and can be followed more readily.

In the interpretation of these polarograms, one must keep in mind that the heights of

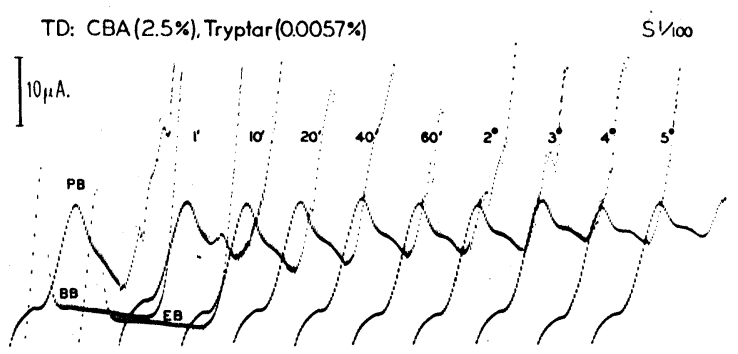

Fig. 2. Tryptic digests of $2.5 \mathrm{~g} / 100 \mathrm{ml}$ GBA in $\mathrm{pH} 7.1$ phosphate buffer as a function of time (Procedure I). $\operatorname{Trypsin}\left(\mathrm{A}_{\mathrm{L}}\right), 0.0057 \mathrm{~g} / 100 \mathrm{ml}$.

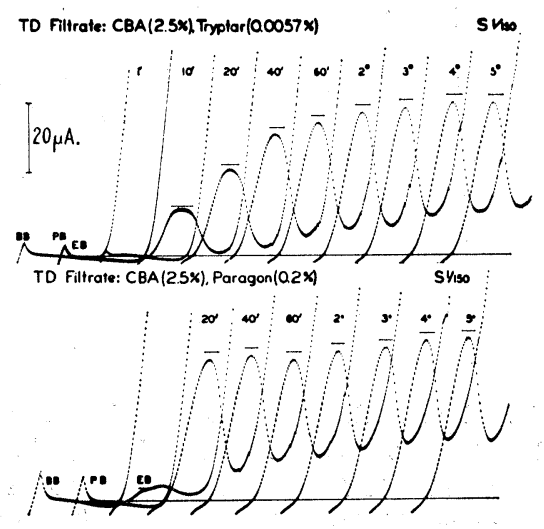

Fig. 3. Filtrates from tryptic digests of $2.5 \mathrm{~g} / 100 \mathrm{ml} \mathrm{CBA}$ in $\mathrm{pH} 7.1$ phosphate buffer as a function of time (Procedure II). Upper Polarogram : Trypsin ( $\left.A_{L}\right)$, $0.0057 \mathrm{~g} / 100 \mathrm{ml}$; Lower Polarogram : Trypsin (P), $0.2 \mathrm{~g} / 100 \mathrm{ml}$.

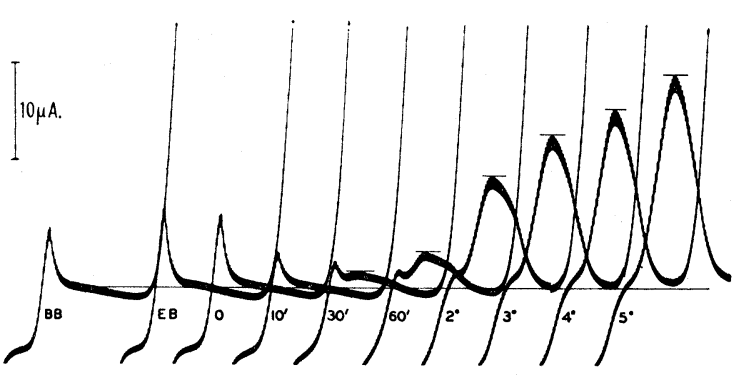

Fig. 4. Filtrates from tryptic digests of $0.5 \mathrm{~g} / 100 \mathrm{ml} \mathrm{CBA}$ in $\mathrm{pH} 7.1$ phosphate buffer as a function of time (Procedure II). Trypsin $\left(\mathrm{A}_{\mathrm{L}}\right), 0.0005 \mathrm{~g} / 100 \mathrm{ml}$. 
catalytic polarographic waves are not linear functions of the concentration of reactive material, but reach limiting values at high concentrations.* As will be shown, this statement holds for all the catalytic waves of tryptic digests studied by us, in contradiction to Stokrova's claim that the wave height produced by split products is a linear function of their concentration "within the defined range" (15-50 $\mathrm{gg}$ of trypsin of unknown but presumably high acitivity). Although we have attempted to duplicate her procedure as much as possible, we have never seen such linearity when we used highly active, crystalline trypsin samples.

Filtrate Material from Tryptic Digests of $C B A$ : In order to have some means for a quantitative analysis of the filtrate (F) substance from the tryptic digestion (TD) of cry-

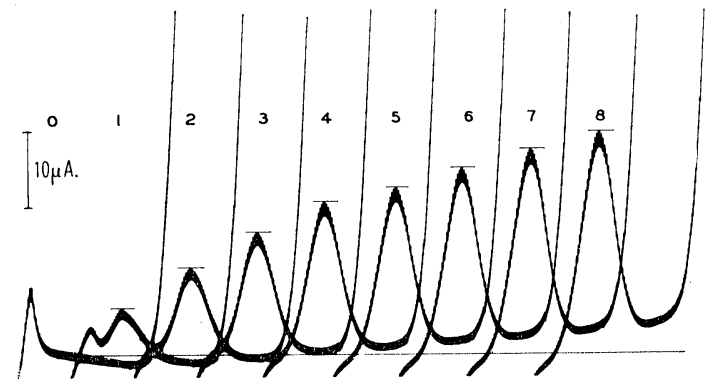

Fig. 5. Dilutions of filtrate from 5 hour digest of $0.5 \mathrm{~g} / 100$ $\mathrm{ml} \mathrm{CBA}$ and $0.005 \mathrm{~g} / 100 \mathrm{ml}$ trypsin $\left(\mathrm{A}_{\mathrm{L}}\right)$ in $\mathrm{pH} 7.1$ phosphate buffer (Procedure II). To $2.0 \mathrm{ml}$ TriCo buffer was added $0.2 \mathrm{ml}$ phosphate buffer containing portions of the filtrate in the ratio of $0: 1: 2: 3:$ $4: 5: 6: 7: 8$.

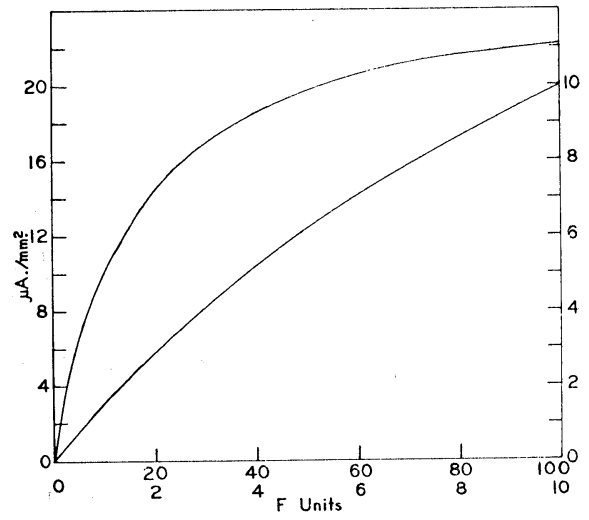

Fig. 6. F-Unit calibration curve for filtrate material from tryptic digests of native GBA (Procedure II). The scale on the left refers to the top curve and to the larger F-Unit scale; that on the right (also in $\mu \mathrm{A} / \mathrm{mm}^{2}$ ) refers to the lower curve and to the smaller F-Unit scale. stalline bovine albumin (CBA), we constructed a calibration curve on the basis of known dilutions of numerous filtrates with high catalytic currents (for an example, see Figure 5). We found that all such curves could be superimposed after correction for concentration and therefore could be treated as representing a single substance. Furthermore, when we plotted the inverse function, e.g., 1/wave height vs. 1/ concentration, a straight line could be drawn through the experimental points. This enabled us to construct the calibration curve shown in Figure 6. In this, the concentration of the unknown F-material, giving rise under the given conditions to a catalytic wave equal to $1 \mu \mathrm{A} / \mathrm{mm}^{2}$ current density is called one F-Unit, (FU). Such an F-unit does not necessarily represent the concentration of a single substance, but, as will be shown later, it can be used to characterize a single substance or groups of substances that show identical polarographic behavior. The concentration of such other Fmaterials can then also be represented by corresponding F-units.

*) This is particularly important when relatively large enzyme blanks are involved. Waves caused by these blanks must be evaluated in terms of F-units before they can be substracted from the other results. 
Nature of the F-Material: A number of experiments have been performed in an attempt to find out more about the nature of the F-material ${ }^{3)}$. In Figure 7 is shown the effect of prolonged dialysis of such filtrate material. The top polarogram presents the effect of dilution of a typical sulfosalicylic acid filtrate from CBA after tryptic digestion at $\mathrm{pH}$ 7.1. Note that there is only one peak, corresponding to the first wave of the protein doublewave, down to the lowest concentration used. Also note that with increasing concentration there is an increase in the third wave, i.e., the height of the minimum following the catalytic wave. Furthermore, the cobalt maximum is complety suppressed at the higher concentrations. The effect of dialysis is demonstrated by the lower polarogram of Figure 7. Apparently the maximum suppressor is largely removed and the minimum following the catalytic wave is always equal to the cobalt diffusion current. This suggests that the compounds responsible for the maximum and the minimum currents must have relatively low molecular weights. The slight asymmetry of the peak of the catalytic wave does not necessarily mean the presence of a second wave, especially since to date no theoretical explanation is available for the decrease in current following the peak on any of the cobalt-catalyzed waves.

The F-material is relatively heat-resistant. Evaporation to dryness on a steam bath, followed by dissolution in water equal in volume to the original solution does not alter its polarographic activity, as may be seen from Figure 8. Preliminary attempts to determine the cysteine content of the dialyzed F-material after hydrolysis with concentrated hydrochloric acid have not produced conclusive answers. Polarograms of such hydrolysates always showed a definite although very small wave in DiCo buffer that was absent in TriCo buffer, but the quantitative aspects of the analyses were never quite satisfactory,

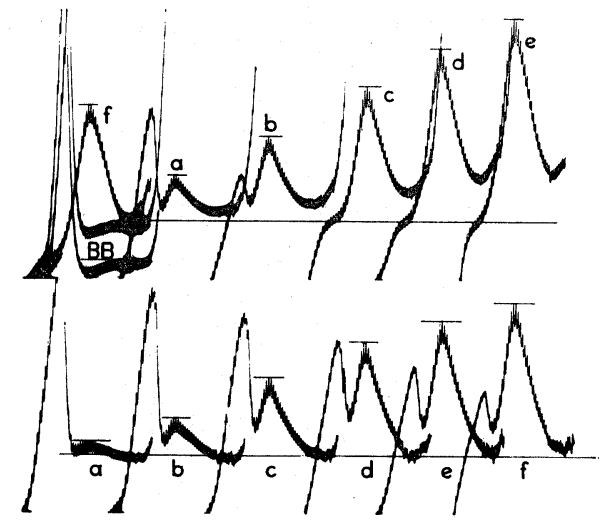

Fig. 7. Dilutions of filtrate from 4 hour digests of $2.5 \mathrm{~g} / 100 \mathrm{ml} \mathrm{CBA}$ and $0.5 \mathrm{~g} / 100 \mathrm{ml}$ trypsin (P) in pH 7.1 phosphate buffer (Procedure II). To $5.0 \mathrm{ml}$ TriCo buffer was added 0.5 $\mathrm{ml}$ distilled water containing portions of the filtrate in the ratios of $1: 2: 4: 6: 8:$ 10 (curves $a-f$ ). Upper polarogram : Filtrates before dialysis (curve $f$ is at $1 / 150$, curves $a-e$ are at 1/100 galvanometer sensitivity). Lower Polarogram : Filtrates after dialysis of 4 days against phosphate buffer followed by 6 days against distilled water. At sensitivity $1 / 100$. BB : Buffer blank at two galvanometer sensitivities.

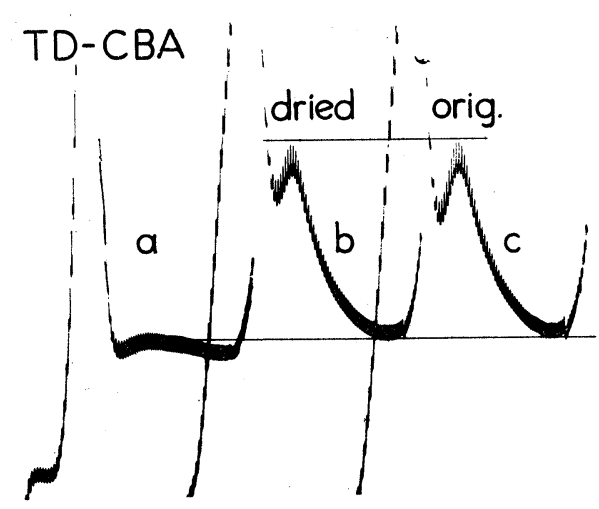

Fig. 8. Dialyzed filtrate from tryptic digest of GBA, as in Figure 7.

(a) $5.0 \mathrm{ml}$ TriCo buffer $+0.5 \mathrm{ml}$ distilled water.

(b) $5.0 \mathrm{ml}$ Trico buffer $+0.5 \mathrm{ml}$ of $2.0 \mathrm{ml}$ dialyzed filtrate dried over steam bath and then made up to $2.0 \mathrm{ml}$ with distilled water.

(c) $5.0 \mathrm{ml}$ Trico buffer $+0.5 \mathrm{ml}$ dialyzed filtrate. 
because of the small quantities of material involved.

Kinetics of the Tryptic Digestion of $C B A$ :

If a polarogram, such as the one shown in Figure 4 is analyzed in terms of F-Units on the basis of the calibration curve of Figure 6, a linear increase in the concentration of the end-products (F-material) is observed as a function of time (Figure 9, curve A). This is in accord with the general finding that the enzymatic action of trypsin starts as a zero

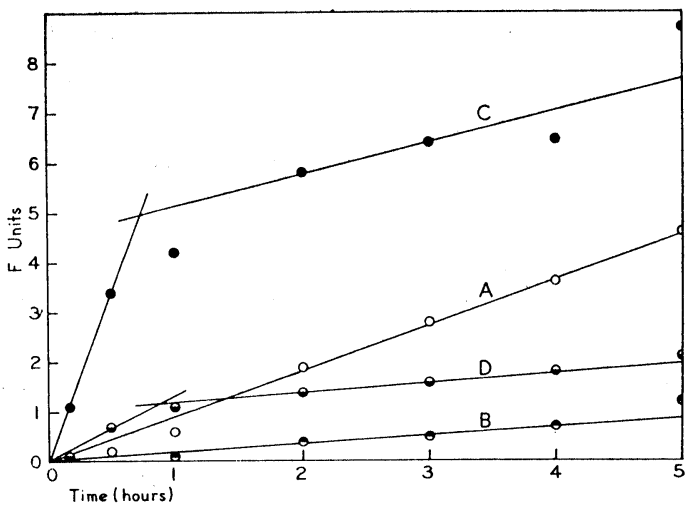

Fig. 9. Graph of F-Units, formed, as a function of time, from digests of CBA and trypsin $\left(A_{L}\right)$. Concentrations :

(A) $0.5 \mathrm{~g} / 100 \mathrm{ml} \mathrm{CBA} \mathrm{;} 0.0005 \mathrm{~g} / 100 \mathrm{ml}$ enzyme.

(B) $0.15 \mathrm{~g} / 100 \mathrm{ml} \mathrm{CBA}$; $0.0005 \mathrm{~g} / 100 \mathrm{ml}$ enzyme.

(C) $0.5 \mathrm{~g} / 100 \mathrm{ml} \mathrm{CBA} ; 0.005 \mathrm{~g} / 100 \mathrm{ml}$ enzyme.

(D) $0.15 \mathrm{~g} / 100 \mathrm{ml} \mathrm{CBA} ; 0.005 \mathrm{~g} / 100 \mathrm{ml}$ enzyme.

order reaction. However, this rate is usually not maintained over a very long period of time, whereas in the present case it lasts for all of the five hours of digestion. Curve B of Figure 9 also shows a zero order reaction at the same trypsin concentration but with a lower substrate concentration, $(0.15 \mathrm{~g} / 100$ $\mathrm{ml} \mathrm{CBA,} \mathrm{vs.} 0.5 \mathrm{~g} / 100 \mathrm{ml}$ for curve A). The slope of the straight lines should be proportional to the activity (or concentration, if the same enzyme is used) of the enzyme. Obviously this is only true at the same substrate concentration; we find the slopes in a ratio of $5: 1$, when the substrate concentrations are in a ratio of $5: 1.5$.

When the ratio of enzyme concentration to substrate concentration is increased, a different picture presents itself. The linear portion of the F-Unit vs. time curve lasts for a much shorter time, after which there is an asymptotic approach to a limiting value (See curves C and D of Figure 9). At both of the given concentrations of substrate, the ratios of the slopes of the zero order reactions for the two enzyme concentrations are about $1: 7.5$ instead of the expected ratio of $1: 10$. This discrepancy is probably caused by the fact that in this instance the indicated concentrations of enzyme were not actually determined in solution, but based merely on the weight of the small quantities of enzyme that had been weighed out.

Instead of drawing a smooth curve through the experimental points, we have arbitrarily drawn straight lines through the second asymptotic portion of curves $\mathrm{C}$ and $\mathrm{D}$ of Figure 9 which cross with the lines representing the zero order reaction. This was done to emphasize a phenomenon which, we believe, warrents further investigation. We speculate that the crossing point of the two sets of straight lines suggests that up to a certain point, determined by the concentration of substrate, F-material is produced at a uniform rate from sites on the protein that are readily accessible. This rate is fast in the presence of much enzyme and slower when the enzyme concentration is less. When the readily split-off products are gone, a new rate starts which is governed by a slower process. This may involve some denaturation of the substrate, essential before more material can be split off. In agreement with this view is the fact that the crossing points are 
roughly proportional to the substrate concentrations even up to CBA concentrations of $2.5 \mathrm{~g} / 100 \mathrm{ml}$ (as in Figure 3A). We found ratios of $1: 5: 20$ for the crossing points in $50-57 \mu \mathrm{g} / \mathrm{ml}$ trypsin $\left(\mathrm{A}_{\mathrm{L}}\right)$ digests of CBA solutions with concentration ratios of $3: 10: 50$. If our speculation is correct, one should be able to maintain the zero order reaction for any desired length of time by a judicious choice of enzyme and substrate concentrations.

Stokrova's Trypsin Assay ${ }^{13}$ : When we tried to apply this method in a study of the stability of trypsin solutions ${ }^{5}$ ) we found it rather insensitive and easily affected by certain conditions that had not been sufficiently stressed. For instance, Stokrova claims an accuracy of $2 \%$ for this assay and states that "in place of albumin it is possible also to use any protein or their mixture whose reaction with trypsin splits off polarographically active products." $\left.{ }^{\prime 3}\right)$ We found that this is misleading because serum, which certainly contains albumin, also contains inhibitors for this reaction. In our own experience with fractions prepared by Cohn's alcohol fractionation technique ${ }^{18)}$ we found evidence of inhibitor present in all fractions, (even fraction $\mathrm{V}$ if this was not carefully purified) with a preponderance in fraction IV.

Another important point to consider is whether the protein is in the native state or whether it is more or less denatured. We have shown previously ${ }^{1}$ that alkaline denaturation of various serum protein fractions produced sulfosalicylic acid-soluble polarographically active products, with the notable exception of albumin and $\gamma$-globulin. Albumin is the better of the two as substrate for the polarographic trypsin assay since it does yield filtrate material upon tryptic digestion, whereas $\gamma$-globulin does not, unless it has been previously denatured in some way ${ }^{6}$. However, albumin, after denaturation, also produces more filtrate material during tryptic digestion than when it is in the native state.

It will be shown later that Stokrova's method, because of the buffer used, actually depends in part on some denaturation of the albumin coincident with the proteolysis by the enzyme. This apparently has not been considered by Stokrova who incubates different quantities of enzyme with different amounts of ammonia buffer in an open test tube at $35^{\circ} \mathrm{C}$ in order to get a calibration curve.

In testing Stokrova's method we have followed her procedure in all details with one exception: In the Trico buffer we used $0.8 M$ instead of $1 M$ ammonium hydroxide. Previous experience ${ }^{4}$ has taught us that such TriCo buffers differ but little in their effectiveness.

Procedure III : To $0.5 \mathrm{ml}$ of a $3 \mathrm{~g} / 100 \mathrm{ml}$ solution of serum albumin in water is added from 0.1 to $0.5 \mathrm{ml}$ of a trypsin solution $\left(15 \mathrm{mg} / 100 \mathrm{ml}\right.$ trypsin in $0.01 . M \mathrm{CaCl}_{2}$ (in $0.001 N \mathrm{HCl}$ ) and the volume is brought to $1.5 \mathrm{ml}$ with an ammonia buffer $\left(0.1 \mathrm{M} \mathrm{NH}_{4} \mathrm{Gl}\right.$ and $\left.0.1 M \mathrm{NH}_{4} \mathrm{OH}\right)$. The mixture is digested at $35^{\circ} \mathrm{C}$ for exactly 20 minutes; then $0.5 \mathrm{ml}$ of it is added to $1.0 \mathrm{ml}$ of sulfosalicylic acid $(20 \mathrm{~g} / 100 \mathrm{ml}$ solution) which precipitates the remaining large molecules. After standing for 10 minutes, the solution is filtered through a hard filter paper, $0.2 \mathrm{ml}$ of the filtrate is added to $4 \mathrm{ml}$ standard TriGo buffer and analyzed polarographically open to air, at $25^{\circ} \mathrm{C}$.

Some of the results obtained by us with Stokrova's method are shown graphically in Figure 10. They were obtained with trypsin $\left(\mathrm{W}_{2 \mathrm{x}}\right)$ and crystalline bovine and human albumin (fraction V) as substrates. Notice that human albumin yields more filtrate material than bovine albumin of the same concentration.

Evaluation of Stokrova's Data in Terms of Current Density: It has been established for a 


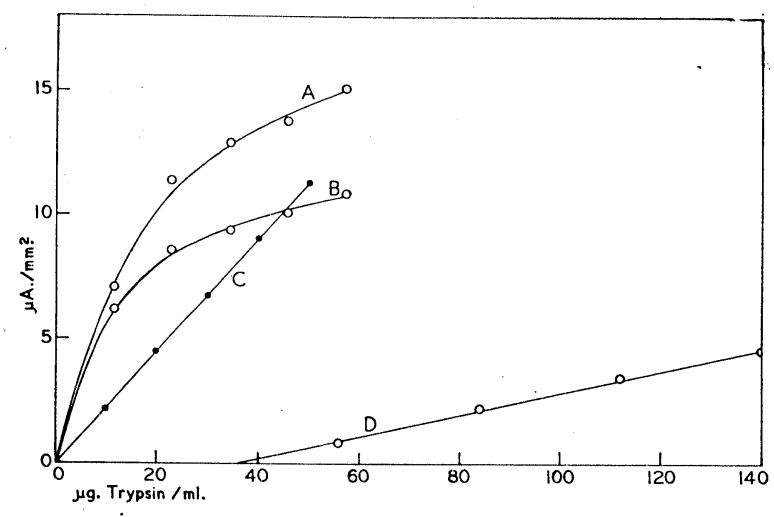

Fig. 10. Test of Stokrova's trypsin assay (Procedure III).

(A) Digest of human albumin (fraction V) with tryp$\sin \left(W_{2 x}\right)$.

(B) Digest of CBA with trypsin $\left(\mathrm{W}_{2 \mathrm{x}}\right)$.

(C) Data from Stokrova (13), (see text).

(D) Digest of CBA with trypsin (P). long time that the heights of catalytic waves, when expressed in terms of current density, are independent of the particular characteristics of the capillary used and its drop time ${ }^{22}$. For the past 15 years, Müller has therefore urged that current density values be reported for such currents. Nevertheless, this information is very seldom given in publications concerning cobaltcatalyzed waves, so that quantitative comparisons are not always possible. Sometimes however, enough information can be extracted from a paper to permit a reasonable estimate of the cur-

rent densities involved. This is true of Stokrova's paper ${ }^{13)}$ from which we have used: (1) Data for $m$ and $t$ which we assumed to have been measured on open circuit in $0.1 N \mathrm{KGl}$; (2) the values for wave heights, given in $\mathrm{mm}$ in Figure 4 ; and (3) the wave heights together with the scale unit of $10 \mu \mathrm{A}$ of the curves reproduced in Figure 3 of her paper. From $m$ and $t$ we found $W_{0}=8.24 \mathrm{mg}$, which was then used to calculate the surface area $\left(=3.0 \mathrm{~mm}^{2}\right)$ at $-1.6 \mathrm{v}$ in the cobalt buffer by means of the conversion factor given in the Appendix. On the basis of this, the current density values could be calculated which have been plotted as curve $\mathrm{C}$ in Figure 10 for comparison. Although the magnitude of Stokrova's currents is of the same order as ours, we were never able to find the linear relationship between current and enzyme concentration claimed by her. Only in the case of the crude trypsin $(\mathrm{P})$ preparation, which has less than one tenth the activity of trypsin $\left(\mathrm{W}_{2 \mathrm{x}}\right)$ did we find a behavior similar to Stokrova's product (see curve $\mathrm{D}$ in Figure 10). However, in this case the straight line relationship between enzyme and current does not extrapolate back to zero.

Proof of Protein Denaturation in Stokrova's Trypsin Assay: Compared to Stokrova's procedure, our previous analysis is much less sensitive. For instance Figure 4 shows that trypsin $\left(\mathrm{A}_{\mathrm{L}}\right)$ with similar activity as sample $\left(\mathrm{W}_{2} \mathrm{x}\right)$, acting on one third as much CBA produces essentially no filtrate material in 20 minutes. The difference, therefore, must lie in the $\mathrm{pH}$ and the kind of buffer used.

The $\mathrm{pH}$ of Stokrova's digest medium is about 9.3 to 9.5. It varies, depending on the amount of buffer used to complete the $1.5 \mathrm{ml}$ volume, and it can be altered radically if not great care is used to carry out the digestion in deep enough test tubes so that loss of ammonia by air convection is minimized.

When we substituted barbiturate buffer of $\mathrm{pH} 9.6$ to avoid change in $\mathrm{pH}$ by loss of ammonia, or a phosphate buffer of $\mathrm{pH} 7.1$, we found the digestion reduced to about one fourth that in the ammonia buffer of $\mathrm{pH}$ 9.5. Even less digestion occurred when the ammonia buffer had been adjusted to $\mathrm{pH} 7.25$ with $1 \mathrm{~N} \mathrm{HCl}$. This led us to the experi- 
ment illustrated in Figure 11 which proved that the digestion with ammonia buffer at $\mathrm{pH} 9.5$ causes a denaturation of the protein that does not yield filtrate material unless further digested by trypsin. Curve $b$ in Figure 11 shows the filtrate wave when CBA was digested with trypsin $\left(\mathrm{A}_{\mathrm{L}}\right)$ for 20 minutes at $35^{\circ} \mathrm{C}$. in an ammonia buffer of pH 9.48. Curve $f$ represents an experiment in which the ammonia buffer was brought to $\mathrm{pH} 7.25$ with $\mathrm{HCl}$ before the digestion, with essentially negative results. Curve $e$ was obtained in a parallel experiment in which the substrate was digested first for 20 minutes at $35^{\circ} \mathrm{C}$ in ammonia buffer of $\mathrm{pH} 9.48$ in the absence of enzyme. Subsequently the mixture was brought to $\mathrm{pH} 7.24$ with $1 \mathrm{~N} \mathrm{HCl}$, an equivalent amount of the enzyme was added, and then this mixture was also digested for 20 minutes at $35^{\circ} \mathrm{C}$. The latter procedure definitely produced polarographically active material, although not to the same extent as Stokrova's procedure (curve $b$ ). Comparison blanks (curves $d$ and $g$ ) showed that no filterable polarographically active material is produced in the absence of trypsin.

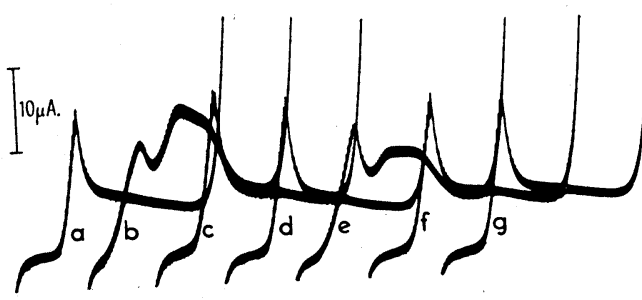

Fig. 11. Effect of ammonia buffer on digestion of CBA with trypsin $\left(A_{L}\right)$. To $2.0 \mathrm{ml}$ of TriCo buffer was added $0.1 \mathrm{ml}$ of :

(a) $20 \mathrm{~g} / 100 \mathrm{ml}$ sulfosalicylic acid.

(b) $-(g)$ Filtrates (obtained after 20 minutes' digestion at $35^{\circ} \mathrm{C}$ ) of $1.0 \mathrm{ml} 3 \mathrm{~g} / 100 \mathrm{ml}$ CBA plus

(b) $0.2 \mathrm{ml}$ enzyme $+1.6 \mathrm{ml} \mathrm{pH} 9.48$ ammonia buffer $+0.2 \mathrm{ml} \mathrm{H}_{2} \mathrm{O}$.

(c) $1.6 \mathrm{ml} \mathrm{pH} 9.48$ ammonia buffer +0.4 $\mathrm{ml} \mathrm{H} \mathrm{H}_{2} \mathrm{O}$.

(d) $1.6 \mathrm{ml}$ pH 9.48 ammonia buffer followed by another digestion of 20 minutes at 35 ${ }^{\circ} \mathrm{C}$ after the addition of $0.14 \mathrm{ml} 1 \mathrm{~N} \mathrm{HGl}$ which brought the $\mathrm{pH}$ to 7.24 .

(e) as (d) but with the further addition of $0.2 \mathrm{ml}$ enzyme for the second period of digestion.

(f) $0.2 \mathrm{ml}$ enzyme $+1.6 \mathrm{ml} \mathrm{pH} 7.25 \mathrm{am}-$ monia buffer $+0.2 \mathrm{ml} \mathrm{H}_{2} \mathrm{O}$.

(g) $1.6 \mathrm{ml} \mathrm{pH} 7.25$ ammonia buffer $+0.4 \mathrm{ml}$ $\mathrm{H}_{2} \mathrm{O}$.

Proposed New Trypsin Assay with Alkali Denatured Crystalline Bovine Albumin (dGBA): As a consequence of the foregoing and other studies on the tryptic digestion of denatured albumin, we have developed a technique resembling to a certain extent Ansons' hemoglobin method $^{14}$ because it requires a carefully prepared denatured substrate. Our biggest problem was the stoppage of the alkaline denaturation of albumin after a given time and the prevention of further spontaneous changes. We have tried to solve it by the addition of urea and by rapid neutralization and storage of the substrate at $-5{ }^{\circ} \mathrm{C}$. This method has yielded reproducible results for freshly prepared substrates but it has failed to provide substrates that remain useful for more than three hours. Complications arising from self-digestion of trypsin (which also produces polàrographically active material) are negligible since the method is so sensitive that only very small concentrations of trypsin are needed.

The digestion time has been reduced to 10 minutes. This seems to be the practical minimum without putting too much strain on the accuracy of timing.

Procedure IV : Not more than 12 tubes containing $1.0 \mathrm{ml}$ of the trypsin solutions to be assayed and a tube containing freshly denatured CBA solution are equilibrated at $37{ }^{\circ} \mathrm{C}$ in a water bath for about 5 minutes. The trypsin solutions should contain between 10 and $100 \times 10^{-6}$ [T.U.] units and be acidified (0.001 $\mathrm{N}$ hydrochloric acid) to prevent premature self-digestion of the sample during storage and tempe- 
rature equilibration. At time zero and every 30 seconds thereafter $1.0 \mathrm{ml}$ of a freshly prepared denatured GBA solution is pipetted into the different trypsin-containing tubes and mixed well with the contents. This is best done by closing off the test tube with parafilm and repeatedly inverting the tube, so that any traces adhering to the walls are properly mixed. Exactly 10 minutes following each addition, $8 \mathrm{ml}$ of a $20 \mathrm{~g} / 100 \mathrm{ml}$ solution of sulfosalicylic acid is pipetted into each tube, mixed well with the tryptic digest and left standing at room temperature for another 10 minutes. After that time, the material is filtered through Whatman $\# 5$ filter paper. The resulting clear filtrate is used as soon as convenient for polarographic analysis. We found that standing for a day at room temperature did not affect the filtrates. By this procedure duplicate filtrates from 6 different trypsin samples can be prepared for polarographic analysis in about one hour.

The polarographic analysis is carried out at $25^{\circ} \mathrm{C}$ in an open vessel on $1.0 \mathrm{ml}$ of the filtrate added to $9.0 \mathrm{ml}$ of TriCo buffer. The height of the catalytic double wave thus obtained is evaluated in terms of current density and the corresponding enzymatic activity in trypsin units is read from the standard curve shown in Figure 15. Knowing the concentration of the trypsin test solution in terms of $\mu \mathrm{g}$ protein/ml, one can then readily calculate the activity of the sample per unit weight of dissolved protein.

\section{Preparation of the denatured $C B A$ solution :}

A $25 \mathrm{ml}$ Erlenmeyer flask containing a mixture of $2.0 \mathrm{ml}$ of $10 \mathrm{~g} / 100 \mathrm{ml}$ solution of urea and 0.5 $\mathrm{ml}$ of $1.0 \mathrm{~N}$ sodium hydroxide is equilibrated in a water bath at $37{ }^{\circ} \mathrm{C}$ for about 5 minutes. Then $2.5 \mathrm{ml}$ of freshly prepared $6 \mathrm{~g}$ per $100 \mathrm{ml}$ solution of CBA in water is pipetted into the flask. The mixture is shaken and kept for exactly 20 minutes at $37^{\circ} \mathrm{C}$. Immediately after removal from the bath, $5.0 \mathrm{ml}$ of ice-cold water and a small magnetic stirrer are added and the flask is put into a $-5{ }^{\circ} \mathrm{C}$ cold bath where it is shaken for a few minutes to hasten temperature equilibrium. The flask is then removed, placed on a MagMix stirrer and $0.62 \mathrm{ml}$ of $1.0 \mathrm{M}$ potassium acid phosphate is added drop by drop from a burette under vigorous stirring. After this the mixture is quantitatively transferred to a $25 \mathrm{ml}$ graduate cylinder with the aid of some distilled water and eventually brought to a final volume of $15.0 \mathrm{ml}$ with water. It is then stored in the cold bath at $-5{ }^{\circ} \mathrm{C}$ until used. This entire procedure requires about 35 minutes.

The denatured CBA solution should have a $\mathrm{pH}$ between 7.1 and 7.2 when checked with a $\mathrm{pH}$ meter at room temperature. It should be used within 3 hours after preparation. Polarographic curves of tryptic digestions for which it serves as substrate, diminish as it ages (in 21 and 96 hours, the loss in wave height is $21 \%$ and $38 \%$ respectively).

In Figure 12 are shown duplicate analyses obtained with this new dCBA method for different concentrations of trypsin $\left(\mathrm{A}_{\mathrm{L}}\right)$. Notice that a double-wave is obtained in all of them and that the second wave is higher than the first. This condition prevails even in very dilute solutions (see Figure 13); hence the height of the second wave is used for comparison.

Proposed Method for the Differentiation of Different F-Materials of Unknown Composition: We have seen earlier (Figure 5) that tryptic digests of native albumin produced F-material that showed only the first catalytic protein wave in TriCo buffer. It is obvious from Figure 13 that the filtrate material following tryptic digestion of denatured albumin differs from the F-material since it produces two waves. The filtrate material formed in Stokrova's method seems to represent still other products since it produces a somewhat broadened first wave in TriGo buffer. We have found that plotting of the inverse functions, i.e., 1/concentration vs. 1/wave height, gives straight lines (in accordance with Langmuir's adsorption isotherm) that can be extrapolated to zero (i.e., infinite concentration). As an example, the data of Figure 12, representing known trypsin concentrations, and of Figure 13, representing known dilutions of an unknown concentration are thus plotted as curves A and B in Figure 14. Note that they extrapolate to the same value, 


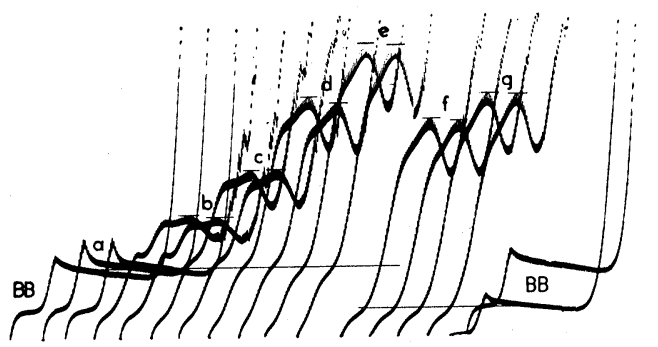

Fig. 12. Duplicate analyses of filtrates from tryptic digests of denatured GBA. (Procedure IV). Concentration of trypsin $\left(\mathrm{A}_{\mathrm{L}}\right)$ in digest : (a) $0,(b) 1,(c) 2$, (d) $4,(e) 6,(f) 8$, and $(g) 10 \mu \mathrm{g} / \mathrm{ml}$. Sensitivities $1 / 100$ for $(a)-(e)$ and $1 / 150$ for $(f)$ and $(g)$.

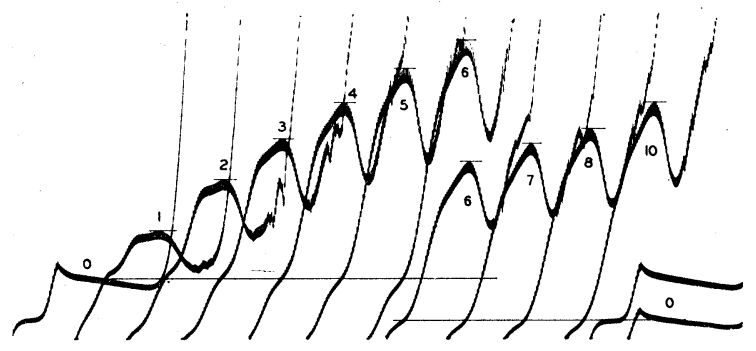

Fig. 13. Dilutions of filtrate from tryptic digest of denatured CBA (Procedure IV). To $9.0 \mathrm{ml}$ TriCo buffer was added $1.0 \mathrm{ml} 20 \mathrm{~g} / 100 \mathrm{ml}$ sulfosalicylic acid containing portions of the filtrate in the ratios of $0: 1: 2: 3: 4: 5: 6: 7: 8: 10$ (as indicated on the polarogram). Sensitivities $1 / 100$ and $1 / 150$.

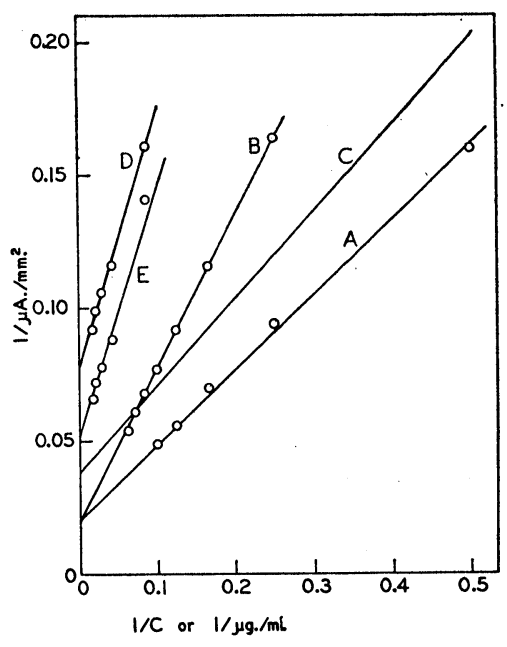

Fig. 14. Graph of inverse functions : $1 /$ current density $v s .1 / C$. ( $C$ is either in arbitrary units or in $\mu \mathrm{g}$ enzyme/ml.)

(A) Data from Figure 12.

(B) Data from Figure 13.

(C) Data from Figure 6.

(D) Data from Figure 10, Curve $B$.

(E) Data from Figure 10, Gurve A.

namely the inverse of the limiting wave height. We have found that this is true for all concentrations of substrate and enzyme as long as we deal with the same reaction, such as the digestion of alkaline denatured CBA by trypsin in a $\mathrm{pH} 7.1$ phosphate buffer. However, when the substrate is altered, the limiting wave height is different, and, we assume, so are the products. Curve $C$ of Figure 14 shows the mean of many analyses in which the substrate was native CBA. Even Stokrova's procedure yields different products, because the denaturation by the ammonia buffer is not the same as an alkaline denaturation. Curves D and $\mathbf{E}$ of Figure 14 furthermore illustrate that differences in the filtrate material can be recognized by this extrapolation technique when the substrate is human instead of bovine albumin.

Master Curve for Trypsin Assay: The straight line relationship shown in curve A of Figure 14 can be used to average the results of several experiments and thus establish the relationship between enzyme concentration and the polarographic wave heights after a specific tryptic digestion. If the activity of the enzyme sample is known, the polarographic wave heights can then be related directly to units of tryptic activity. This we have done in the construction of the master curve shown in Figure 15, in which current density values applicable to any dropping mercury electrodes, no matter what the drop time or $\mathrm{size}^{22}$, are related to trypsin units. It is based on the average of repeated polarographic analyses of the reactions of trypsin $\left(\mathrm{A}_{\mathrm{L}}\right)$ for which we had established an activity of 5.8 $\times 10^{-3}$ [T.U.] $]_{\mathrm{mg}}^{\mathrm{Hb}}$ by other methods ${ }^{5}$. This trypsin unit is defined according to Anson and 
Mirsky" as follows: "One unit of trypsin produces in 1 minute at $35.5^{\circ} \mathrm{C}$ in $6 \mathrm{ml}$ of digestion mixture an amount of color-producing substance not precipitable with trichloroacetic acid which gives the same color as 1 milliequivalent of tyrosine."

Unfortunately this is not the only unit by which the activity of trypsin has been defined. For instance, the assay as carried out by the Armour Laboratories ${ }^{23}$ is very similar to Anson's hemoglobin method $^{14}$ but the Armour Tryptar Unit [ATU] is defined ${ }^{24}$ as follows: "One Tryptar unit is that amount of Tryptar which upon incubation at 25.0 $\pm 0.1{ }^{\circ} \mathrm{C}$ for ten minutes with a suitable preparation of pure hemoglobin will cause the decomposition of the hemoglobin to such an extent that the amount of hydroxyaryl substances liberated will upon reaction with Folin-Giocalteau phenol reagent result in the formation of a colored solution of equal intensity to that resulting from the reaction of $5.52 \times 10^{-6}$ millimoles of tyrosine with Folin-Ciocalteau reagent. One thousand Armour Units of activity is equivalent to $1 \mathrm{mg}$ of tyrosine and is the equivalent of $1 \mathrm{mg}$ of Tryptar." (The trypsin $\left(\mathrm{A}_{\mathrm{L}}\right)$ used by us actually had 1740 [ATU] per mg, as determined by this technique.) In contrast to this, trypsin assayed by the method of Schwert and Takenaka ${ }^{17}$ is evaluated in [STU] units defined ${ }^{20)}$ as follows: "A trypsin unit is that activity causing a change in optical density of 0.001 per minute under the specified conditions."

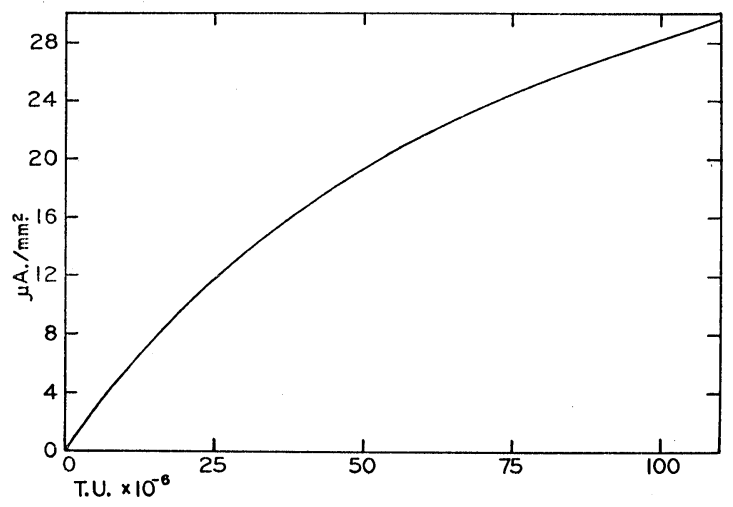

Fig. 15. Master Curve for Procedure IV showing the relation between Trypsin Units $\left([T U] \times 10^{-6}\right.$ ) and current density.

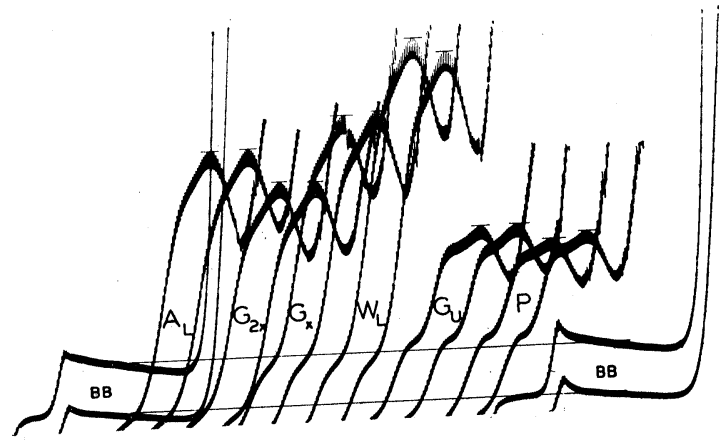

Fig. 16. Duplicate assays of six samples of trypsin by means of Procedure IV. For analysis of the data see Table I. Galvanometer sensitivities $1 / 100$ and $1 / 150$.
Obviously there is no theoretical way to compare these different units. However, having assayed the same trypsin $\left(\mathrm{A}_{\mathrm{L}}\right)$ sample by all three methods, we have obtained the following average conversion factors per mg of enzyme protein :

$$
\begin{aligned}
& 5800 \times 10^{-6}[\text { T.U. }]_{\operatorname{mg}}^{\mathrm{Hb}} \\
& =1740[\mathrm{ATU}]=5500 \text { [STU], }
\end{aligned}
$$

or, as a first approximation a ratio of $10: 3: 10$ if the powers of 10 of the [T.U.] are ignored. Thus the data of Figure 15 can also be used to assay trypsin in these other units by the described method, after the results have been converted into current densities.

The polarogram reproduced in Figure 16 shows duplicates of the assays of six different enzyme preparations. The corresponding currents, current densities, and activities are listed in Table I along with a similar assay of trypsin $\left(\mathrm{W}_{2 \mathrm{x}}\right)$. The last column of this table gives the relative activities of the various enzyme preparations with trypsin $\left(A_{L}\right)$ serving as standard of referen- 
ce. The values thus found are in good agreement with our results obtained by the hemoglobin and N-benzoyl-L-arginine ethyl ester methods ${ }^{5}$.

Table I. Polarographic Assay of Various Trypsin Preparations with Procedure IV.

\begin{tabular}{|c|c|c|c|c|c|c|}
\hline Enzyme & $\begin{array}{c}\text { Concentration } \\
\text { in Digest } \\
\mu \mathrm{g} / \mathrm{ml}\end{array}$ & $\begin{array}{c}\text { Catalytic } \\
\text { Gurrent } \\
\mu \mathrm{A}\end{array}$ & $\begin{array}{l}\text { Current } \\
\text { Density } \\
\mu \mathrm{A} / \mathrm{mm}^{2}\end{array}$ & $\begin{array}{c}\text { Trypsin } \\
\text { Units } \\
\text { [T.U.] } \times 10^{-6}\end{array}$ & \begin{tabular}{|c|} 
Activity \\
{$[$ T.U. $] \times 10^{-6}$} \\
$\mu \mathrm{g}$
\end{tabular} \mid & $\begin{array}{c}\text { Relative } \\
\text { Activity } \\
\% \\
\text { of } \mathrm{A}_{L}\end{array}$ \\
\hline Trypsin $A_{L}$ & 9.4 & 49.1 & 20.8 & 56.5 & 6.0 & 100 \\
\hline Trypsin $G_{2 x}$ & 8.5 & 42.4 & 18.0 & 45.0 & 5.3 & 88 \\
\hline $\operatorname{Trypsin} \mathrm{G}_{\mathrm{x}}$ & 4.6 & 30.1 & 12.8 & 28.5 & 6.2 & 103 \\
\hline Trypsin $W_{L}$ & 9.4 & 38.5 & 16.3 & 38.5 & 4.1 & 69 \\
\hline Trypsin $G_{P}$ & 43. & 15.5 & 6.6 & 12.0 & 0.3 & 5 \\
\hline Trypsin P & 35. & 14.0 & 5.9 & 10.0 & 0.3 & 5 \\
\hline Trypsin $W_{2 x}$ & 9.2 & 50.8 & 21.5 & 59.0 & 6.4 & 107 \\
\hline
\end{tabular}

\section{Summary}

The proteolytic action of trypsin on crystalline bovine albumin in $\mathrm{pH} 7.1$ phosphate buffer has been studied polarographically by observing the cobalt-catalyzed currents of this protein and its degradation products.

Changes in the albumin molecule, observable in divalent cobalt buffer, require relatively high enzyme concentrations, suggesting that impurities in the trypsin preparation are responsible.

Split products from albumin as the result of tryptic digestion are separated from the protein in a sulfosalicylic acid filtrate and analyzed in trivalent cobalt buffer. They produce a single peaked catalytic wave when they are liberated from native albumin and a protein double wave when $\mathrm{NaOH}$-denatured albumin is used as substrate. Still another product is formed when the substrate has been denatured in an ammonia buffer of $\mathrm{pH} 9.5$. The various filterable products can be distinguished from each other on the basis of dilution studies, because the function between 1 /concentration and 1 /current is linear and can be extrapolated to a different zero (limiting current at infinite concentration) for each product.

At certain ratios of enzyme to substrate concentrations, the tryptic digestion of native CBA yields filterable material at a constant rate (up to 5 hours). This is interpreted as a release of readily accessible filtrate material. If the enzyme/substrate ratio is increased, the duration of the zero order reaction is decreased and another reaction (denaturation ?) becomes rate limiting. The polarographic response of dialyzed filtrate material from tryptic digests of native CBA is not altered by drying the material over a steam bath.

Tryptic digestion of 10 minutes' duration at $37^{\circ} \mathrm{C}$ of alkali-denatured $\mathrm{CBA}$ in a $\mathrm{pH}$ 7.1 phosphate buffer results in the release of large amounts of filterable material which are proportional to the activity of the trypsin present. This reaction has been developed into a trypsin assay suitable for very small quantities (as little as $5 \mu \mathrm{g}$ of trypsin). A master curve has been prepared showing the relationship between current densities and trypsin units, which is applicable to all kinds of dropping mercury electrodes and drop times. Approximate conversion factors have also been given for three of the more common trypsin units. 


\section{Appendix}

Calculation of the Surface Area of the DME at - $1.6 \mathrm{v}$ in Cobalt Buffer from $m$ and $t$ Values Obtained on Open Circuit in $0.1 \mathrm{~N} \mathrm{KCl}$.

A knowledge of the size of the surface area of the dropping mercury electrode at an applied voltage of about $-1.6 \mathrm{v}$ is very important for the evaluation of catalytic currents in terms of current densities. Yet, hardly any experimenters have given this information in the past. They often report values for $m$ and $t$, but unfortunately do not always state the conditions of their measurement. If one may assume that these two values are obtained on open circuit in $0.1 \mathrm{~N}$ potassium chloride solution, one can make an estimate of the surface area at $-1.6 \mathrm{v}$ in a cobalt buffer as follows :

The drop weight $W$ (in $\mathrm{mg}$ ) is given ${ }^{25}$ by the equation

$$
W=6.41 \times 10^{-4} \rho \sigma
$$

where $\rho$ is the radius of the capillary orifice (in microns) and $\sigma$ is the surface tension (380 dynes $\mathrm{cm}^{-1}$ in $0.1 \mathrm{~N} \mathrm{KCl}$ ). We have found in this laboratory that $\sigma$ is about $80 \%$ of the value in $0.1 \mathrm{~N} \mathrm{KCl}$ (or 304 dynes $\mathrm{cm}^{-1}$ ), when the electrode is dropping in a cobalt buffer and is polarized to $-1.6 \mathrm{v}$ (vs. S.C.E.). Therefore the drop weight under these conditions is also $80 \%$ of the drop weight in $0.1 \mathrm{~N} \mathrm{KGl}$ on open circuit, which shall be designated by $W_{0}$.

The surface area, A, of the "ripe" drop is known to be $0.8517 W^{2 / 3}{ }^{22)}$; hence the surface area at $-1.6 \mathrm{v}$ in a cobalt buffer is $0.8517(0.80)^{2 / 3} W_{0}^{2 / 3}=0.734 W_{0}^{2 / 3}$. (For completeness, it may be mentioned that if the radius of the orifice, $\rho$, is known, the surface area of the drop at $-1.6 \mathrm{v}$ in a cobalt buffer is found to be $0.286 \rho^{2 / 3}$.)

\section{Bibliography}

1) O.H. Müller, "Polarographic Behavior of Various Plasma Protein Fractions," Ghapter 16 in T. Shedlovsky, ed., Electrochemistry in Biology and Medicine, Wiley and Sons, New York, 1955.

2) O.H. Müller, "Polarographic Studies of Proteins and their Degradation Products. IV. The Activation and Decay Reactions of Proteins during the Digest Test," in Symposium Die Polarographie in der Chemotherapie, Biochemie und Biologie, Jena 1962 (in print).

3) O.H. Müller and M.J. Elwood, Fed. Proceedings, 13, 103 (1954).

4) O.H. Müller, "Polarographic Analysis of Proteins, Amino Acids, and Other Compounds by Means of the Brdička Reaction" in D. Glick, ed., Methods of Biochemical Analysis, Vol. 11, Wiley \& Sons, New York (in print).

5) O.H. Müller and I. Yamanouchi, Arch. Bioch. Biophys. 76, 328, (1958).

6) O.H. Müller and I. Yamanouchi, Fed. Proceedings, 15, 133 (1956).

7) G. Tropp, F. Geiger, and W. Stoye, Z. physiol. Chem., 277, 192 (1943).

8) G.J. Millar, Biochem.J., 53, 385 (1953).

9) L. Jühling, G. Tropp, and E. Wöhlisch, Z. physiol. Chem., 262, 210 (1939).

10) C. Tropp and W. Herrbach, Z. physiol. Chem., 281, 50 (1944).

11) T. Hata and S. Matsushita, Bull. Research Inst. Food Sci., Kyoto Univ. No. 10, 59 (1952).

12) M.L. Grossley, R.H. Kienle, B. Vassel, and G.L. Cristopher, J. Lab. Clin. Med. 27, 213 (1941).

13) S. Stokrova, Chem. Listy, 48, 1082 (1954).

14) M.L. Anson, J. Gen. Physiol., 22, 79 (1938).

15) M.L. Anson, and A.E. Mirsky, J. Gen. Physiol. 17, 151 (1933).

16) M. Kunitz, J. Gen. Physiol., 30, 291 (1946-7).

17) G.W. Schwert and Y. Takenaka, Biochem. et Biophys. Acta, 16, 570 (1955). 
18) E.J. Cohn, F.R.N. Gurd, D.M. Surgenor, B.A. Barnes, R.K. Brown, G. Derouaux, J.M. Gillespie, F.W. Kahnt, W.F. Lever, C.H. Liu, D. Mittelman, R.F. Mouton, K. Schmid, and E. Uroma, J. Am. Chem. Soc., 72, 465 (1950).

19) A.G. Gornall, G.J. Bardawill, and M.M. David, J. Biol. Chem., 177, 751 (1949).

20) Worthington Biochemical Corp., Freehold, N.J., “Descriptive Manual \#8,” April 1956.

21) J.H. Northrop, J. Gen. Physiol., 16, 339 (1932-3).

22) O.H. Müller and J.S. Davis, Jr., Arch. Biochem., 15, 39 (1947).

23) Kindly communicated to us by Mr. R.J. Seidel, of Armour Laboratories, Kankakee, Ill.

24) Pamphlet of the Armour Laboratories accompanying their first shipment of "Tryptar" (1952).

25) O.H. Müller, J. Am. Chem. Soc., 66, 1019 (1944). 